\title{
GLYCOREGULATION DURING PREGNANCY
}

\author{
Violeta Mladenovic ${ }^{1}$, Milica Dimitrijevic-Stojanovic ${ }^{2}$, Djuro Macut ${ }^{3}$, Aleksandar Djukic ${ }^{1}$ \\ ${ }^{1}$ Department of Internal Medicine, Faculty of Medical Sciences, University of Kragujevac, Serbia \\ ${ }^{2}$ Center for Molecular Medicine and Stem Cell Research, Faculty of Medical Sciences, University of Kragujevac, Serbia \\ ${ }^{3}$ Medical Faculty, University of Belgrade, Serbia
}

\section{GLIKOREGULACIJA TOKOM TRUDNOĆE}

\author{
Violeta Mladenović́ ${ }^{1}$, Milica Dimitrijević-Stojanović ${ }^{2}$ Đuro Macut ${ }^{3}$, Aleksandar Đukić ${ }^{1}$ \\ ${ }^{1}$ Katedra za internu medicinu, Fakultet medicinskih nauka, Univerzitet u Kragujevcu, Srbija \\ ${ }^{2}$ Centar za molekulsku medicinu i istraživanje matičnih ćelija, Fakultet medicinskih nauka, Univerzitet u Kragujevcu, Srbija \\ ${ }^{3}$ Medicinski fakultet, Univerzitet u Beogradu, Srbija
}

\begin{abstract}
Pregnancy is a period marked by profound changes in a woman's hormonal status and metabolism, including the development of a carbohydrate-intolerant state. Gestational diabetes mellitus (GDM) is defined as any degree of glucose intolerance with onset or first recognition during pregnancy.

The aim of this study was to estimate and analyse the parameters of glycaemic control during pregnancy. We stratified patients into the following three groups according to OGTT results: normal glucose tolerance (NTG), gestational impaired glucose tolerance (GIGT) and GDM.

We investigated 92 pregnant women, diagnosed with vital and desired pregnancy up to 12 weeks of gestation, who had signed informed consent forms. Among them, 7 pregnant women had a spontaneous abortion, while 8 pregnant women dropped out, so a total of 77 pregnant women completed the trial. Most of the women examined had no risk factors (48\%), while 35\% of the women had one risk factor. The current study demonstrates that normal glucose tolerance was shown in 59 (76.6\%) participants, while some form of glucose intolerance (GIGT or GDM) was shown in 18 (23.4\%) patients. Our findings revealed an increase in glucose intolerance with advancing pregnancy (in the second and third trimester). In conclusion, we demonstrate that the difference in the quality of glycaemic control during pregnancy is manifested in the second and third trimester, until it manifests in the first trimester. These findings underpin the clinical significance of discovering GDM.
\end{abstract}

Keywords: Pregnancy, glycoregulation

\section{SAŽETAK}

Trudnoća je period koji karakterišu znatne promene u hormonskom statusu $i$ metabolizmu žene, ali i stanje intolerancije ugljenih hidrata. Gestacijski dijabetes (GDM) se definiše kao bilo stepen netolerancije glukoze sa početkom ili prvim pojavljivanjem tokom trudnoće.

Cilj ovog istraživanja je bio da se procene i analiziraju parametri metaboličke kontrole tokom trudnoće. Prema rezultatima OGTT-a, podelili smo pacijente u tri grupe: normalna tolerancija glukoze (NTG), smanjena tolerancija na glukozu (GIGT) i GDM. Ispitivali smo 92 trudnice kod kojih je postavljena dijagnoza vitalne $i$ željene trudnoće do 12 nedelje, koje su potpisale informisani pristanak. Među njima, 7 trudnica je imalo spontani pobačaj, dok je 8 trudnica odustalo, tako da je 77 trudnica završilo ispitivanje. Većina ispitanih žena nije imalo faktore rizika (48\%), dok je 35\% imalo jedan faktor rizika.

Ova studija pokazuje da je NTG zastupljena kod 59 $(76,6 \%)$ ispitanica, dok neki oblik intolerancije glukoze (GIGT ili GDM) ima 18 (23,4\%) ispitanica. Naši rezultati pokazuju porast intolerancije glukoze sa napredovanjem trudnoće (u drugom i trećem trimestru). Pokazano je i da se razlika u kvalitetu glikoregulacije tokom trudnoće manifestuje u drugom i trećem trimestru, dok se ne manifestuje u prvom trimestru. Ovi nalazi podupiru klinički značaj otkrivanja GDM.

Ključne reči: trudnoća, glikoregulacija 


\section{INTRODUCTION}

Pregnancy is a period marked by profound changes in a woman's hormonal status and metabolism (1). During pregnancy, $\beta$ cells normally increase their insulin secretion to compensate for a decrease in insulin sensitivity (2). Pregnancy is a carbohydrate-intolerant state, but only a small proportion of pregnant women will develop diabetes (1). In all pregnancies, insulin resistance increases as the pregnancy develops due to rising circulating concentrations of insulin antagonists such as cortisol, prolactin, human placental lactogen, and leptin. This resistance results in increasing need for insulin, especially in the second half of pregnancy. If insulin secretion is impaired, the enhanced insulin resistance will give rise to hyperglycaemia (3).

During the first two-thirds of gestation, the mother is in an anabolic condition, increasing her fat depots (4). During the last third of gestation, the mother switches to a catabolic condition (5). Insulin resistance tends to increase in physiological pregnancy, following gradually rising levels of foeto-placental hormones (1). In response to this imbalance, the pancreas normally compensates with a higher insulin secretion (4). When this compensatory mechanism fails, glucose intolerance develops (6).

Gestational diabetes mellitus (GDM) is defined as any degree of glucose intolerance with onset or first recognition during pregnancy $(4,7)$. It does not exclude the possibility that unidentified glucose intolerance may have preceded the pregnant state $(8,9)$. The prevalence varies for different populations, and ranges from 7 to $18 \%$ (7). Screening for this disease is recommended for the highrisk and intermediate groups any time during pregnancy, or between 24 and 28 weeks in the latter group (4). The diagnosis of GDM is based on an oral glucose tolerance test, OGTT (9). GDM usually appears in the third trimester as the placenta matures and placental hormones contribute to insulin resistance, which usually recedes after the placenta is delivered (10). Glucose crosses the placenta and stimulates foetal insulin production, while maternal or exogenous insulin does not (4). Since many patients with GDM develop type 2 diabetes, and both diseases are characterized by insulin resistance, some authors postulate that they represent points on a continuum of glucose intolerance (11).

The traditional risk factors for GDM are high maternal age, weight and parity, previous delivery of a macrosomic infant and family history of diabetes (3). Although controversy exists regarding the specific protocols to apply, screening for GDM by OGTT in pregnancy has become a standard element of obstetrical care (12). With this testing, GDM is diagnosed based on blood glucose levels that exceed specific glycaemic thresholds (2). These criteria were chosen to identify women at high risk for developing diabetes after pregnancy, or were derived from criteria used for nonpregnant individuals and not necessarily to identify pregnancies with increased risk for adverse perinatal outcome (8). Clinical detection of GDM is carried out to iden- tify pregnancies at increased risk for perinatal morbidity and mortality $(10,13)$. Most women with GDM appear to have $\beta$-cell dysfunction that occurs against a background of chronic insulin resistance (14).

GDM is associated with increased foetal and maternal complications, including congenital malformation, macrosomia, birth injuries, hypoglycaemia and pre-eclampsia, increased incidence of caesarean section and postpartum diabetes in mother (9). Clinical evidence has confirmed that the main goal of glycaemic management in GDM is to keep the mother's blood glucose levels within the normal range (6).

Women with GDM are at high risk for having or developing diabetes after pregnancy $(7,13)$. After pregnancy, the main focus of clinical care should be on reducing the risk of diabetes and detecting and treating diabetes that does develop. Measurement of fasting glucose in the postpartum period will identify women with increased fasting glycaemia who should have an OGTT sometime during the first 2-6 months postpartum and, if not diabetic, annual testing for diabetes (14).

The aim of this study was to estimate and analyse the parameters of glycaemic control during pregnancy.

\section{MATERIALS AND METHODS}

\section{Subjects.}

This study included 92 women with a diagnosis of vital and desired pregnancy in the first trimester, and 77 of them finished the study. Exclusion criteria for all subjects included age $<18$ years, diabetes, diseases of the pancreas, liver diseases, kidney diseases, hypertension, corticosteroid treatment, cancer, physical disabilities or psychiatric disorders. The study was performed according to the principles of good clinical practice and was approved by the Ethical Committee of Clinical Center of Kragujevac. Written informed consent was obtained from all participants.

The study protocol included the following four visits for each pregnant woman: in the first (10-14 weeks of gestation), second (20-24), and third trimesters (30-34) and 8 weeks after delivery.

Pregnant women underwent a diagnostic $3 \mathrm{~h}, 100-\mathrm{g}$ oral glucose tolerance test (OGTT) after a $12 \mathrm{~h}$ overnight fast. Venous blood samples for measurement of plasma glucose levels and insulin concentrations were drawn in the fasting state and at $0 \mathrm{~min}, 1 \mathrm{~h}, 2 \mathrm{~h}$ and $3 \mathrm{~h}$ after ingestion of the 100 -g glucose drink. None of the respondents had disturbance of glycaemic control at baseline.

$H b A 1 c$ was determined with immunoinhibition commercial reagents and latex agglutination inhibition process (measured absorbance caused agglutination at $700 \mathrm{~nm}$ ), expressed as a percentage (\%) (reference value 4-7).

Based on the criteria using the OGTT proposed by the American Diabetes Association (ADA), GDM was diagnosed if two or more values reached or exceeded the following thresholds: fasting glucose $>5.3 \mathrm{mmol} / \mathrm{L}, 1 \mathrm{~h}$ 
Table 1. Anthropometric values, personal history and risk factorsrisk factors

\begin{tabular}{|ll|}
\hline Maternal age (min-max) & $30,8 \pm 4,7(19-41)$ \\
\hline$\leq 25$ & $4 / 77(5,2 \%)$ \\
\hline $25-34$ & $56 / 77(72,7 \%)$ \\
\hline$\geq 35$ & $17 / 77(22,1 \%)$ \\
\hline Body weight in first trimester (kg) (min-max) & $63 \pm 8,49(48-90)$ \\
\hline Body height (m) (min-max) & $169 \pm 5,7(155-186)$ \\
\hline Body mass index (BMI-kg/m2) & $22 \pm 2,6(17-30,88)$ \\
\hline BMI 18,5-24,8 kg/m2 & $70 / 77(90,9 \%)$ \\
\hline BMI 25-31,0 kg/m2 & $9 / 77(9,1 \%)$ \\
\hline Weight gain until delivery (kg) (min-max) & $12,7 \pm 1,49(9-16)$ \\
\hline Obesity (\%) & $3 / 77(3,9 \%)$ \\
\hline Hypertension (\%) & $4 / 77(5,2 \%)$ \\
\hline Previously treated sterility (\%) & $7 / 77(9,1 \%)$ \\
\hline Previous use of metformin (\%) & $3 / 77(3,9 \%)$ \\
\hline Previous gestational diabetes mellitus (\%) & $8 / 77(23,5 \%)$ \\
\hline Smoking Yes & $18 / 77(23,4 \%)$ \\
\hline No & $47 / 77(61 \%)$ \\
\hline Previous (until pregnancy) & $12 / 77(15,6 \%)$ \\
\hline Concomitant disease & $6 / 77(7,8 \%)$ \\
\hline Autoimmune thyroid disease & \\
\hline Hypertension & \\
\hline
\end{tabular}

glucose $>10.0 \mathrm{mmol} / \mathrm{L}, 2 \mathrm{~h}$ glucose $>8.6 \mathrm{mmol} / \mathrm{L}$, and $3 \mathrm{~h}$ glucose $>7.8 \mathrm{mmol} / \mathrm{L}(15,16)$.

The OGTT result was considered normal (normal glucose tolerance, NGT) if plasma glucose levels in the fasting state and at $1 \mathrm{~h}, 2 \mathrm{~h}$ and $3 \mathrm{~h}$ during the OGTT were less than the thresholds of the ADA criteria. Based on the four blood glucose values obtained during the three-hour $100 \mathrm{~g}$ OGTT, participants were classified as having either GDM (defined by two or more values above criterion thresholds), gestational impaired glucose tolerance (GIGT) (defined by only one value above criterion thresholds) or normal glucose tolerance (NGT) (no elevated values).

\section{Statistical analysis}

The median value, standard deviation (SD), minimum and maximum value, as well as the normality of distribution of all continuous variables were examined. Continuous variables with normal distribution were presented as the mean \pm SD in the text and tables, and those with a distribution that was not normal as the median and range of the minimum-maximum value. Continuous variables were tested for normality of distribution and were compared among four subgroups using the one-way analysis of variance or the Kruskal-Wallis test. Categorical variables are presented as proportions and were assessed with the $\chi^{2}$ test or Fisher's exact test. A p-value less than 0.05 was considered statistically significant. All statistical calculations were carried out using commercial, standard software package SPSS, version 20.0.

\section{RESULTS}

We investigated 92 pregnant women with a diagnosis of vital and desired pregnancy up to 12 weeks of gestation who had signed informed consent forms. Among them, 7 pregnant women had a spontaneous abortion, while 8 pregnant women dropped out, so a total of 77 pregnant women completed the trial.

Demographic characteristics of the subjects are summarized in Table 1.

The largest number of the study population was aged $25-34$ years $(72.7 \%)$, with an average age of $30.8 \pm 4.7$ (1941) years, usually with medium (51.9\%) and high (40.3\%) education levels. Body mass index in the first trimester was most often within the reference range for the general population, while $9 \%$ of the women were overweight.

Of the study population, $23.4 \%$ of the pregnant women smoked during pregnancy. The most commonly associated disease during pregnancy was an autoimmune thyroid disease (25.9\%), followed by antiphospholipid syndrome (9\%) and hypertension (7.8\%). Of the 34 respondents who were multipara, $23.5 \%$ of pregnant women had had previous GDM, as shown in Table 1.

The following risk factors for abnormal glucose regulation (GDM or GIGT) were taken into consideration: obesity, age over 35 years, previous GDM, birth weight in previous pregnancies $>4 \mathrm{~kg}$, family history of diabetes, previous use of metformin, previously treated polycystic ovary syndrome, parity $\geq 3$. Most examined women had no risk factors (48\%), while $35 \%$ had one risk factor (Table 2 ).

The examination of the existence of abnormal glucose regulation (GDM or GIGT) during pregnancy by trimester demonstrated an increase in disorders of glucose tolerance with advancing pregnancy (in the second and third trimester). After childbirth, all subjects showed normal glucose tolerance (Table 3).

ANOVA-repeated measurements are compared fasting glucose (FBG) at 4 times: OGTT1, OGTT2, OGTT3 and OGTT4. A significant effect of time, Vilks lambda $=0.527, \mathrm{~F}=22.175, \mathrm{p}<0.001$, multivariate partial eta squared $=0.473$.

There are intergroup differences in the values of FBG (during the test period), namely: FBG1 compared to FBG2 $(\mathrm{p}=0.001)$, FBG1 compared to FBG3 ( $\mathrm{p}<0.001)$, FBG2 compared to FBG 4 ( $\mathrm{p}<0.001)$, FBG3 in relation to FBG4 $(\mathrm{p}<0.001)$, but there is no significancet when comparing

Table 2. Frequency of risk factors for pathological glucose tolerance

\begin{tabular}{|l|l|l|l|l|l|}
\hline No. of risk factors & $\mathbf{0}$ & $\mathbf{1}$ & $\mathbf{2}$ & $\mathbf{3}$ & total \\
\hline $\begin{array}{l}\text { Normal glucose } \\
\text { tolerance, NGT }\end{array}$ & $31 / 59$ & $19 / 59$ & $6 / 59$ & $3 / 59$ & $59(100 \%)$ \\
\hline $\begin{array}{l}\text { Gestational } \\
\text { impaired glucose } \\
\text { tolerance, GIGT }\end{array}$ & $2 / 9$ & $6 / 9$ & $1 / 9$ & 0 & $9(100 \%)$ \\
\hline $\begin{array}{l}\text { Gestational diabetes } \\
\text { mellitus, GDM }\end{array}$ & $4 / 9$ & $2 / 9$ & $2 / 9$ & $1 / 9$ & $9(100 \%)$ \\
\hline
\end{tabular}


Table 3. Frequency of abnormal glucose regulation (subject-stratified according to glucose tolerance status) during examined period

\begin{tabular}{|l|l|l|l|l|}
\hline OGTT & $\begin{array}{l}\mathbf{1 .} \\
\text { trimester }\end{array}$ & $\begin{array}{l}\mathbf{2 .} \\
\text { trimester }\end{array}$ & $\begin{array}{l}\mathbf{3 .} \\
\text { trimester }\end{array}$ & $\begin{array}{l}\text { After } \\
\text { delivery }\end{array}$ \\
\hline $\begin{array}{l}\text { Normal } \\
\text { glucose } \\
\text { tolerance, } \\
\text { NGT }\end{array}$ & $71(92,2 \%)$ & $67(87 \%)$ & $69(89,6 \%)$ & $77(100 \%)$ \\
\hline $\begin{array}{l}\text { Gestational } \\
\text { impaired } \\
\text { glucose } \\
\text { tolerance, } \\
\text { GIGT }\end{array}$ & $5(6,5 \%)$ & $6(7,8 \%)$ & $4(5,2 \%)$ & 0 \\
\hline $\begin{array}{l}\text { Gestational } \\
\text { diabetes } \\
\text { mellitus, GDM }\end{array}$ & $1(1,3 \%)$ & $4(5,2 \%)$ & $4(5,2 \%)$ & 0 \\
\hline
\end{tabular}

FBG1 in relation to FBG4 $(\mathrm{p}=0.209)$ and FBG2 compared to FBG 3 ( $\mathrm{p}=0.504)$ (Table 4$)$.

One-way analysis of variance indicated that there was no statistically significant difference in mean HbA1c during the test period ( $\mathrm{p}>0.05)$, as shown in Figure 1.

According to OGTT results, we stratified patients into three groups as follows: normal glucose tolerance (NTG), gestational impaired glucose tolerance (GIGT) and gestational diabetes mellitus (GDM).

It has been shown that the average HbA1c in the first trimester is highest in the GDM group, compared to in the second and third trimester; after birth, it is highest in GIGT group. Combined analysis of variance estimated the impact of time and degree of glucose tolerance on HbA1c. There was a statistically significant effect of time on HbA1c (Vilks lambda $=0.849$, multivariate partial eta square $=0.151, \mathrm{p}=0.008)$. There is no interaction between the factors of time and the factor of glucose tolerance (Vilks lambda $=0.879$, multivariate partial eta squared $=0.062$, $\mathrm{p}=0.152)$. Separate influence on glucose tolerance was significant $(\mathrm{F}=4.134$, multivariate partial eta squared $=0.059$, $\mathrm{p}=0.046)$. The intergroup differences compared HbA1c between NTG and GIGT (Vilks lambda $=0.842$, multivariate partial eta squared $=0.158, \mathrm{p}=0.011$ ), between NTG and GDM (Vilksov lambda $=0.856$, multivariate par-

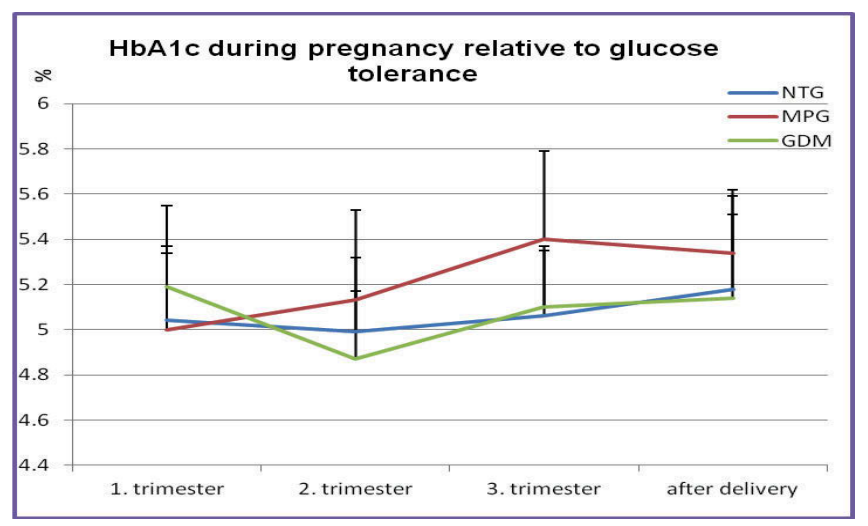

Figure 1. Average values of HbA1c during OGTT $(\mathrm{n}=77)$
Table 4. Average values of glycaemia and insulinaemia during OGTT (n=77)

\begin{tabular}{|l|c|c|c|c|}
\hline $\begin{array}{l}\text { Glycaemia } \\
(\mathbf{m m o l} / \mathbf{L}) \\
\boldsymbol{X} \pm \boldsymbol{S D}\end{array}$ & $\begin{array}{c}\text { 1st } \\
\text { trimester }\end{array}$ & $\begin{array}{c}\text { 2nd } \\
\text { trimester }\end{array}$ & $\begin{array}{c}\text { 3rd } \\
\text { trimester }\end{array}$ & $\begin{array}{c}\text { After } \\
\text { delivery }\end{array}$ \\
\hline $0 \mathrm{~min}$ & $4.42 \pm 0.48$ & $4.13 \pm 0.49$ & $4.04 \pm 0.51$ & $4.55 \pm 0.39$ \\
\hline $60 \mathrm{~min}$ & $6.34 \pm 1.37$ & $6.97 \pm 1.83$ & $7.44 \pm 1.45$ & \\
\hline $120 \mathrm{~min}$ & $5.47 \pm 1.37$ & $5.97 \pm 1.47$ & $6.71 \pm 1.45$ & $5.2 \pm 1.09$ \\
\hline $180 \mathrm{~min}$ & $4.28 \pm 1.32$ & $4.5 \pm 1.47$ & $5.18 \pm 1.6$ & \\
\hline
\end{tabular}

Table 5. Average values of glicemiaglycaemia and HbA1c during OGTT. Normal glucose tolerance, NTG $(\mathrm{n}=59)$

\begin{tabular}{|l|c|c|c|c|}
\hline $\begin{array}{l}\text { Glycaemia } \\
(\mathbf{m m o l} / \boldsymbol{L}) \\
\boldsymbol{X} \pm \boldsymbol{S D}\end{array}$ & $\begin{array}{c}\text { 1st } \\
\text { trimester }\end{array}$ & $\begin{array}{c}\text { 2nd } \\
\text { trimester }\end{array}$ & $\begin{array}{c}\text { 3rd } \\
\text { trimester }\end{array}$ & After delivery \\
\hline $0 \mathrm{~min}$ & $4.38 \pm 0.38$ & $4.07 \pm 0.48$ & $3.92 \pm 0.43$ & $4.51 \pm 0.39$ \\
\hline $60 \mathrm{~min}$ & $5.99 \pm 1.45$ & $6.42 \pm 1.4$ & $6.96 \pm 1.24$ & \\
\hline $120 \mathrm{~min}$ & $5.24 \pm 1.08$ & $5.47 \pm 0.98$ & $6.34 \pm 0.99$ & $5.16 \pm 0.97$ \\
\hline $180 \mathrm{~min}$ & $4.21 \pm 1.29$ & $4.3 \pm 1.28$ & $4.85 \pm 1.37$ & \\
\hline $\boldsymbol{H b A 1 c}(\%)$ & $5.04 \pm 0.3$ & $4.99 \pm 0.33$ & $5.06 \pm 0.29$ & $5.18 \pm 0.41$ \\
\hline
\end{tabular}

Table 6. Average values of glicemiaglycaemia and HbA1c during OGTT. Gestational impaired glucose tolerance, GIGT $(n=9)$

\begin{tabular}{|l|c|c|c|c|}
\hline $\begin{array}{l}\text { Glycaemia } \\
(\mathbf{m m o l} / \mathbf{L}) \\
\boldsymbol{X} \pm \boldsymbol{S D}\end{array}$ & $\begin{array}{c}\text { 1st } \\
\text { trimester }\end{array}$ & $\begin{array}{c}\text { 2nd } \\
\text { trimester }\end{array}$ & $\begin{array}{c}\text { 3rd } \\
\text { trimester }\end{array}$ & After delivery \\
\hline $0 \mathrm{~min}$ & $4.7 \pm 0.47$ & $4.41 \pm 0.59$ & $4.49 \pm 0.66$ & $4.55 \pm 0.43$ \\
\hline $60 \mathrm{~min}$ & $7.31 \pm 2.73$ & $8.06 \pm 1.81$ & $8.91 \pm 1.62$ & \\
\hline $120 \mathrm{~min}$ & $6.23 \pm 1.83$ & $7.01 \pm 1.75$ & $7.14 \pm 1.4$ & $4.88 \pm 1.61$ \\
\hline $180 \mathrm{~min}$ & $4.73 \pm 1.13$ & $4.97 \pm 1.61$ & $5.37 \pm 1.52$ & \\
\hline $\boldsymbol{H b A 1 c} \mathbf{( \% )}$ & $5.0 \pm 0.37$ & $5.13 \pm 0.4$ & $5.4 \pm 0.39$ & $5.34 \pm 0.28$ \\
\hline
\end{tabular}

Table 7. Average values of glicemiaglycaemia and HbA1c during OGTT. Gestational diabetes mellitus, GDM ( $n=9)$

\begin{tabular}{|l|c|c|c|c|}
\hline $\begin{array}{l}\text { Glycaemia } \\
(\mathbf{m m o l} / \boldsymbol{L}) \\
\boldsymbol{X} \pm \boldsymbol{S D}\end{array}$ & $\begin{array}{c}\text { 1st } \\
\text { trimester }\end{array}$ & $\begin{array}{c}\text { 2nd } \\
\text { trimester }\end{array}$ & $\begin{array}{c}\text { 3rd } \\
\text { trimester }\end{array}$ & After delivery \\
\hline $0 \mathrm{~min}$ & $4.35 \pm 0.32$ & $4.23 \pm 0.37$ & $4.39 \pm 0.46$ & $4.47 \pm 0.25$ \\
\hline $60 \mathrm{~min}$ & $7.63 \pm 2.2$ & $9.49 \pm 1.91$ & $9.1 \pm 1.19$ & \\
\hline $120 \mathrm{~min}$ & $6.18 \pm 2.06$ & $8.19 \pm 2.54$ & $8.74 \pm 2.18$ & $5.78 \pm 1.17$ \\
\hline $180 \mathrm{~min}$ & $4.21 \pm 1.74$ & $5.34 \pm 2.17$ & $7.17 \pm 1.82$ & \\
\hline $\boldsymbol{H b A 1 c} \mathbf{( \% )}$ & $5.19 \pm 0.36$ & $4.87 \pm 0.3$ & $5.1 \pm 0.27$ & $5.14 \pm 0.37$ \\
\hline
\end{tabular}

tial eta squared $=0.476, \mathrm{p}=0.018)$ and compared GIGT and GDM (Vilks lambda=0.524, multivariate partial eta squared $=0,476, \mathrm{p}=0.025)$.

\section{DISCUSSION}

GDM is known to be associated with adverse outcomes (AOs) to the mother and the foetus, and the risk for AOs increases with the degree of hyperglycaemia in women with GDM (17). GDM is increasingly recognized 
not only as a serious and frequent complication of pregnancy but also as an opportunity for early prevention of diabetes and other diseases across the lifespan (18). It is expected that the global prevalence of GDM, which is currently from $<1$ to $28 \%$, will continue to grow. It has become clear that there is a large gap between the enormous global number of pregnant women with GDM and the small proportion of women who were diagnosed and left on their own (19). Although the risk of AO associated with GDM is well known, the impact on the health of mothers and neonates is less well known regarding borderline GDM (GIGT), which is characterized by values between NTG and GDM. In the last ten years, the influence of different degrees of tolerance to glucose complications revealed significantly increased risk of preeclampsia, caesarean section, hypoglycaemia and hyperbilirubinemia in GIGT compared to NTG $(20,21)$. Older age, weight gain and BMI are associated with pregnancy outcome at the GIGT. There are data linking elevated BMI with numerous maternal and foetal complications, such as foetal death, preeclampsia, GDM, macrosomia and complicated labour $(22,23)$. A small weight gain is associated with small size for gestational age, while increased body weight is associated with an increased risk of macrosomia, caesarean section and excessive retention of weight after childbirth (24).

Glucose of the mother crosses the placenta, and maternal hyperglycaemia leads to intrauterine hyperglycaemia, foetal hyperinsulinaemia and possible modifications to the growth and development of the foetus (25). Mild hyperglycaemia in women with GDM is associated with increased foetal growth and perinatal morbidity. Less serious forms of glucose intolerance are also associated with increased foeto-maternal morbidity (26).

Women with GDM have a 17-63\% risk of developing type 2 diabetes within 5-16 years. There is also some evidence that further pregnancies accelerate the rate of decline of $\beta$ cell function in women with GDM (3). The severity of glucose intolerance has been reported to influence the rate of preeclampsia. In some studies, less severe forms of glucose intolerance, even in women who were not diagnosed with GDM, have been associated with preeclampsia. Hyperinsulinaemia, which is often associated with glucose intolerance, may also contribute to the pathogenesis of essential hypertension or development of preeclampsia. Other investigators have found that demographic variables that include race, age, and weight also confer an increased risk of preeclampsia $(25,26)$.

The new proposed diagnostic criteria will result in a prevalence of $17.8 \%$ for GDM, doubling the number of pregnant women diagnosed with GDM. These criteria are based on the correlation of glucose and 1.75-fold increased risk of large size for gestational age in the HAPO study. Supporting the Pendersen hypothesis, the results showed a clearly increased risk of these outcomes, and the risk gradually increases with the level of glucose $(17,27)$. While the concentration of FBG shows a trend towards lower as pregnancy progresses, the rise in blood glucose after eating is greater and longer lasting as a result of impaired, insulin-mediated glucose usability, suppression of endogenous glucose production and inadequate insulin increase in the first phase of insulin secretion (28).

In our study, we included 92 pregnant women who met the inclusion criteria, and none of the participants had disturbance of glycaemic control at baseline. The following risk factors for glucose intolerance (GIGT or GDM) were taken into consideration: obesity, older age (over 35 years), previous GDM, birthweight neonates in previous pregnancies $>4 \mathrm{~kg}$, positive family history of DM, previous use of metformin (previously treated polycystic ovary syndrome), and parity $\geq 3$. Most respondents had no risk factors (48\%), while $35 \%$ had one risk factor. The current study demonstrates that normal glucose tolerance was shown in 59 (76.6\%) participants, while some form of glucose intolerance (GIGT or GDM) was shown in $18(23.4 \%)$ patients. are nNumerous risk factors thathave been shown to influence the degree of disorder of glucose tolerance $(r=0.034)$.

There are no clear guidelines for the determination of HbA1c during pregnancy, but it is not routinely recommended for women with GDM. The lifetime of erythrocytes during pregnancy is shortened to 90 days, so its determination is only possible within shorter intervals than in the state outside of pregnancy. The degree of change in HbA1c in pregnancy reflects glycaemic control for the past few weeks. Therefore, the determination of HbA1c during pregnancy is more likely to be used for therapeutic decisions in pregnancy complicated with diabetes, including GDM. Strict glycaemic control is essential to minimize the morbidity and mortality of the mother and foetus $(21,25)$. Women with GDM have several basic defects in glucose metabolism that are unmasked physiologically by IR late in pregnancy, including the production of increased basal insulin and $\beta$ cell dysfunction. In these women, FBG increases, indicating increased basal and the production of $\beta$-cell dysfunction (29).

The treatment of GDM is intended to decrease adverse pregnancy outcomes (28). The HAPO Study (27) reported associations of maternal 'moderate' hyperglycaemia with risks of adverse pregnancy outcome in a very heterogeneous cohort of 25,505 pregnant women from 15 centres in nine countries. This helped to publish the most recent diagnostic criteria by the IADPSG (8), where the same test is used for both screening and diagnosis.

Testing HbA1c in NTG patients has shown a mild insignificant increase as the pregnancy progresses. The HbA1c in patients with GDM at the beginning of pregnancy is elevatedis but is corrected in more heavily pregnant women. This is likely due to therapeutic intervention for the GDM. Pregnant women with GIGT have a good initial state, but as the pregnancy advances, HbA1c increases significantly. There were statistically significant differences in HbA1c between NTG and GIGT, as well as between GIGT and GDM. Pregnant women with GIGT 
remain unrecognized but are at higher risk of adverse outcomes than those with GDM, so it is necessary to detect GIGT to establish good glycaemic control. There is therapeutic intervention only in patients with GDM. An increase of insulin levels during OGTT is expected as pregnancy progresses. There is no one respondent with adverse pregnancy outcomes who had at least one risk factor. Pregnant women with adverse outcomes have significantly higher frequency of glucose intolerance, with adverse outcomes equal to that of GIGT and GDM, so GIGT is not harmless GDM.

Our findings revealed an increase in glucose intolerance with advancing pregnancy (in the second and third trimester). After delivery, all participants exhibited normal glucose tolerance. The weakness of our study is the small cluster/cohort of women. In conclusion, we demonstrate that the difference in the quality of glycaemic control during pregnancy is manifested in the second and third trimester, until it manifests in the first trimester. These findings underpin the clinical significance of discovering GDM.

\section{Acknowledgements}

The authors acknowledge all the women who participated in this study and the medical staff in the Department of Endocrinology, Clinical Centre Kragujevac, and Centre for Molecular Medicine and Stem Cell Research, Faculty of Medicine, University of Kragujevac. This work was supported by grants from the Faculty of Medical Sciences, Kragujevac (project JP 28/12 and 27/12), Serbia.

\section{Conflicts of interest}

The authors declare no financial or commercial conflicts of interest.

\section{REFERENCES}

1. Herrera E, Ortega H. Metabolism in normal pregnancy. In: Hod M, Jovanovic L, Di Renzo G C, de Leiva A et Langer O. Ed. Textbook of Diabetes and Pregnancy, Second edition, London: Informa Healthcare;2008, pp 25-34.

2. Saisho Y, Miyakoshi K, Tanaka M, et al. Beta cell dysfunction and its clinical significance in gestational diabetes. Endocr J 2010;57:973-80.

3. Hyer SL, H.A. Shehata HA. Gestational diabetes mellitus. Current Obstetrics \& Gynaecology 2005;15:368-374.

4. Baz B, Riveline JP, Gautier JF. Gestational diabetes mellitus: definition, aetiological and clinical aspects. Eur J Endocrinol. 2016 Feb;174(2):R43-51

5. Herrera E. Metabolic adaptations in pregnancy and their implications for the availability of substrates to the fetus. Eur J Clin Nutr 2000;54(suppl. 1):S47-S51.
6. Retnakaran R, QI Y, Sermer M, Conelly P, Hanley A, Zonman B. Glucose Intolerance in Pregnancy and Future Risk of Pre-Diabetes or Diabetes. Diabetes Care 2008;31:2026-2031.

7. Diabetes in pregnancy: management of diabetes and its complications from preconception to the postnatal period. NICE guideline, Published: 25 February 2015. nice.org.uk/guidance/ng32.

8. International Association od Diabetes and Pregnancy Study Groups Recommendations on Diagnosis and Classification od Hyperglycemia in Pregnancy. Diabetes Care 2010; 33:676-682.

9. Singh SK, Rastogi A. Gestational diabetes mellitus. Diabetes, Metabolic Syndrome: Clinical Research \& Reviews 2008;2:227-234.

10. Wu ET, Nien FJ, Kuo CH, Chen SC, Chen KY, Chuang LM, Li HY, Lee CN. Diagnosis of more gestational diabetes lead to better pregnancy outcomes: Comparing the International Association of the Diabetes and Pregnancy Study Group criteria, and the Carpenter and Coustan criteria. J Diabetes Investig. 2016 Jan;7(1):121-6.

11. Kelly L, Evans L, Messenger D. Controversies around gestational diabetes. Can Fam Physician 2005;51:68

12. Weile LK, Kahn JG, Marseille E, Jensen DM, Damm P, Lohse N.Global cost-effectiveness of GDM screening and management: current knowledge and future needs. Best Pract Res Clin Obstet Gynaecol. 2015 Feb;29(2):206-24.

13. Krstevska B, Velkoska-Nakova V, Slagjana SK, Sasha JM. Maternal 75-g OGTT glucose levels as predictive factors for large-for-gestational age newborns in women with gestational diabetes mellitus. Arch Endocrinol Metab. 2016 Feb;60(1):36-41

14. Buchanan TA, Xiang AH. Gestational diabetes mellitus. J Clin Invest 2005;115:485-491.

15. American Diabetes Association. Diagnosis and classification of diabetes mellitus. Diabetes Care 2013;36(Suppl. 1):S67-S74.

16. American Diabetes Association. Standards of Medical Care in Diabetes 2013. Diabetes Care 2013;36(Suppl. 1):S11-S66.

17. Jenum A, Mørkrid K, Sletner, Vange S, Torper J, Nakstad B et al. Impact of ethnicity on gestational diabetes identified with the WHO and the modified International Association of Diabetes and Pregnancy Study Groups criteria: a population-based cohort study. European Journal of Endocrinology 2012;166:317-324.

18. Misra S, Dornhorst A. Gestational Diabetes Mellitus: Primum Non Nocere. Diabetes Care 2012;35:1811-13.

19. Visser G, de Valk H. Gestational diabetes: screening for all, which test and which treatment. Expert Rev Endocrinol Metab 2012;7(2):165-167.

20. Simmons D, Moses RG. Gestational Diabetes Mellitus: To Screen or Not to Screen?: Is this really still a question? Diabetes Care 2013;36:2877-2878. 
21. Manzoor N, Moses RG. Diagnosis of gestational diabetes mellitus: A different paradigm to consider. Diabetes Care 2013;36:e187.

22. Ryan E.A. Diagnosing gestatinal diabetes. Diabetologia 2011;54:480-486.

23. Retnakaran R, Qi Y, Sermer M, Connelly P, Zinman B, Hanley A. Comparison of National Diabetes Data Group and American Diabetes Association diagnostic criteria for gestational diabetes in their identification of postpartum risk of glucose intolerance. Diabetes Research and Clinical Practice 2009;85:40-46.

24. Nohr EA, VaethM, Baker JL, Sørensen TIA, Olsen J, Rasmussen KM. Combined associations of prepregnancy body mass index and gestational weight gain with the outcome of pregnancy. Am J Clin Nutr 2008;87:1750-9.

25. Hawkins JS, Lo JY, Casey BM, McIntire DD, Leveno KJ. Diet-treated gestational diabetes mellitus: Comparison of early vs. routine diagnosis. Am J Obstet Gynecol 2008;198:287.e1-287.e6
26. Clausen TD, Mathiesen ER, Hansen T, Pedersen O, Jensen DM, Lauenborg J et al. High prevalence of type 2 diabetes and pre-diabetes in adult offspring of women with gestational diabetes mellitus or type 1 diabetes: the role of intrauterine hyperglycemia. Diabetes Care 2008;31:340-346.

27. HAPO Study Cooperative Research Group, Metzger BE, Lowe LP, Dyer AR, Trimble ER, Chaovarindr U, Coustan DR, et al. Hyperglycemia and adverse pregnancy outcomes. New England Journal of Medicine 2008358 1991-2002.

28. Reece EA, Moore T. The diagnostic criteria for gestational diabetes: to change or not to change? Am J Obstet Gynecol 2013 255-259.

29. Golden S, Bennett W, Baptist-Roberts K, Wilson L, Barone B, Gary T, et al. Antepartum Glucose Tolerance Test Results as Predictors of Type 2 Diabetes Mellitus in Women With a History of Gestational Diabetes Mellitus: A Systematic Review. Gend Med. 2009;6(Suppl 1):109-22. 
$\$$ sciendo 